\title{
The Public Antagonist and Martyr: \\ Reading A.H.J. Dautzenberg against Literary Typologies
}

\author{
INGE VAN DE VEN \\ Tilburg University \\ Tilburg School of Humanities \\ Department of Culture Studies \\ Tilburg University \\ Warandelaan 2 \\ 5037 AB Tilburg, The Netherlands \\ i.g.m.vdven@uvt.nl
}

\begin{abstract}
I analyze the public authorship of Dutch writer A.H.J. Dautzenberg. I disentangle some of the main threads in his literature and public persona, singling out three socio-cultural issues on which he has publicly taken a stance in both his literature and his non-fiction texts. I base my analysis on three types of sources: Dautzenberg's works of literary fiction, appearances in the media, and non-fictional texts. I argue that the case of Dautzenberg brings out the limits of any typology of engaged authorship, autonomous authorship, or stardom, and that his veiled emphasis on factuality under the flag of fiction to an important extent explains the efficiency of his style of media performance, and helps the author generate attention for his work. I conclude that in the final instance, both his work and his media performances are subordinate to his societal engagement, and that therefore, Dautzenberg is a public antagonist first, and an author only secondarily.
\end{abstract}

Keywords: authorship; commitment; Dutch literature; engagement; fiction; media stardom; public intellectuals 


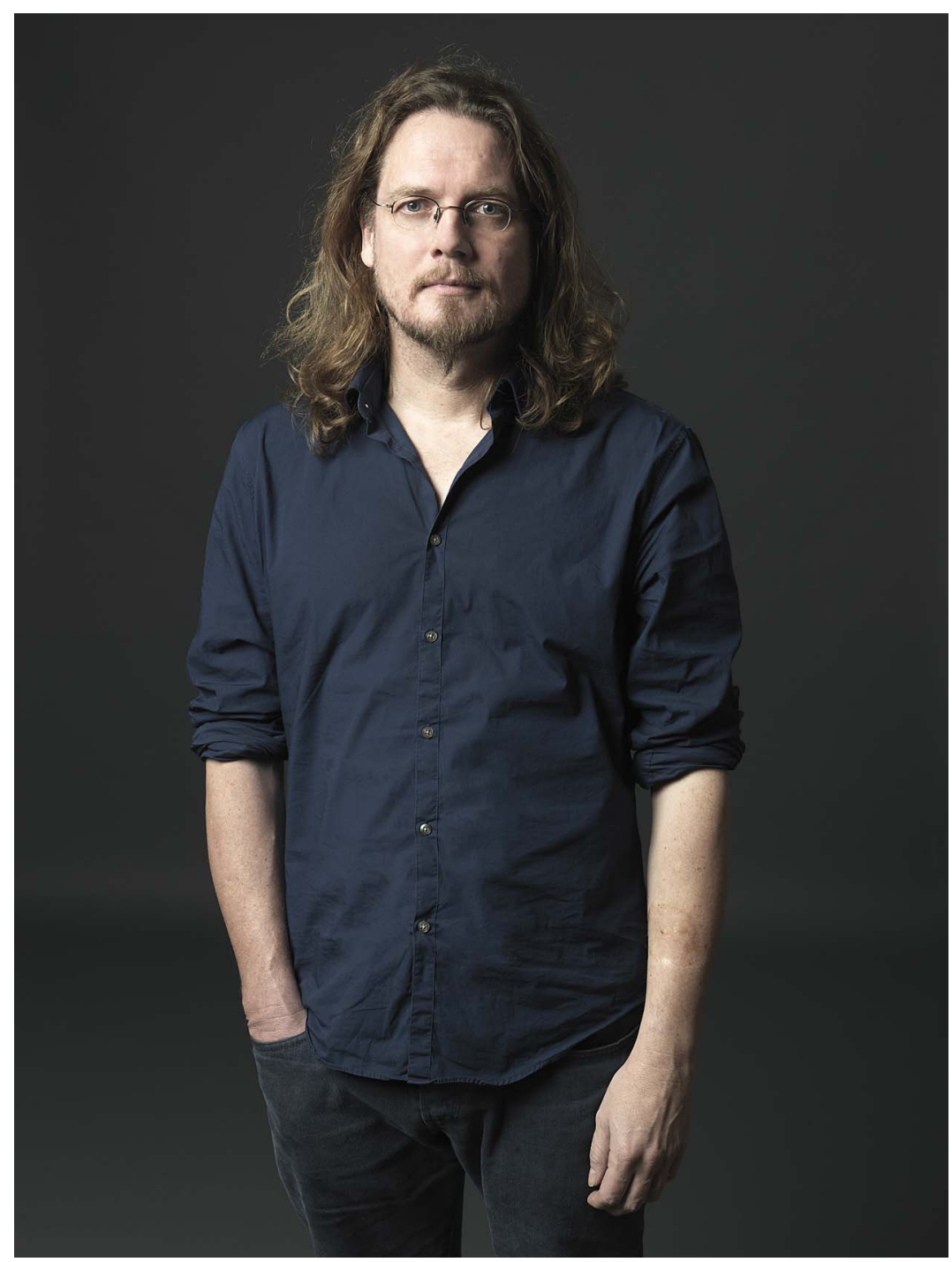

A.H.J. Dautzenberg. Photo: Annaleen-Louwes. 


\section{Introduction}

If there is one contemporary Dutch author who is notoriously hard to pigeonhole, it must be A.H.J. Dautzenberg. Critics have given him many different names, from "the Dutch Dave Eggers" (Cloostermans 2015) to attention seeker (Storm 2011), and from "mythomaniac" (Bell and Punt 2014) to "literary activist" (Thomèse 2015). Trained as an economist as well as a journalist and literary scholar, Dautzenberg wrote for The Financial Times, but achieved notoriety working as a journalist for the VPRO Guide. For this magazine he interviewed Lemmy Kilmister, frontman of heavy metal band Mötörhead, who appeared to possess remarkable analytical insight into the financial crisis. An interview with writer Arnon Grunberg allegedly ended by Dautzenberg popping a zit on the latter's face. These and other pieces, it later turned out, were fabricated. Dautzenberg further shocked and provoked by writing stories describing acts of paedophilia ("Suikerfeest," 2009) and the gory details of murdering the beloved Major Bosshardt, figurehead of the Dutch Salvation Army ("Op bezoek bij majoor Bosshardt," 2009). He published a book of absurdist stories, Vogels met zwarte veren kun je niet vreten [You Can't Eat Birds with Black Feathers, 2011], yet also writes opinion pieces and essays where he clearly states his opinions on societal matters.

The diversity of his output in different genres and media, his tendency to provoke, and his blurring of the boundaries between fiction and non-fiction raise questions about his status in regards to authorship in the public sphere. Can Dautzenberg be characterized as a postmodern ironist, or the contrary, a Dutch proponent of the 'new sincerity' (Wallace 1993)? Is he an ethical avant-gardist, a committed defender of the underdogs in our culture, or a provocateur in an attention economy who goes to great lengths to be noticed by the media? In this article I will try to disentangle some of these threads in Dautzenberg's literature, authorship, and public persona. I single out three socio-cultural issues on which he has publicly taken a stance in both his literature and his non-fiction texts: organ donation, paedophilia, and the Diederik Stapel affair. I base my analysis on three types of sources:

(a) Dautzenberg's works of literary fiction, mainly Samaritaan [Samaritan, 2011], Wie zoet is [Who's Sweet, 2015], and De fictiefabriek [The Fiction Factory, with Diederik Stapel, 2014].

(b) Appearances in the media, for instance talk shows such as Pauw E Witteman (2011 and 2013), and De Wereld Draait Door (2014).

(c) His non-fictional texts: journalistic essays such as "Rafelranden van de moral" [The Frayed Edges of Morality, 2013], and articles in NRC Handelsblad. 
On the basis of this range of sources, is it possible to construe a unified image of Dautzenberg's role as a literary author and public persona? Can his social and ethical engagement, his drive to shock, his anti-establishment attitude, and his playing with truth and fiction, be reconciled and synthesized into a model of what a committed and contrarian authorship could entail today? Or do we have to conclude that these different roles conflict and undermine each other, and ultimately detract from the societal issues he seeks to address? Who is A.H.J. Dautzenberg as public intellectual, star author, and committed writer?

In what follows, I try to set the case study of Dautzenberg against several models of authorship, none of which, we will see, fits him very comfortably: the public intellectual, the twentieth-century (modernist) autonomous writer, and the twenty-first-century star author. Two main points will arise from this analysis. The first is that certain fields of friction and tension will be laid bare when we confront existing theories of public authorship with this case study. The case of Dautzenberg, I set out to show, brings out the limits of any typology of engaged authorship, autonomous authorship, or stardom. Setting these typologies against this work and persona will demonstrate that reality is more complex and unruly, and that models and theories of public engagement are necessarily and inevitably prescriptive and idealistic.

The second point that I wish to make in this article is concerned with a discrepancy in Dautzenberg's works and extra-literary engagement, when it comes to his professed acclaim of fictionalization. On many occasions, the author has underlined the importance of the author's right to fictionalize and confabulate without constraints (Dautzenberg 2014a). Conversely, he expresses disdain for the popularity of the 'true story.'

True stories are popular. Reality scores on TV, in newspapers and in books. Preferably together, nice and cozy, we love to solve as many 'problems' as possible - murders, farmers without wives, neighborly disputes. Detectives are immensely popular. Idealism is unpopular again. The War on Terror and the omnipresent financial crisis are the causes that 'we' again have a pressing need for clarity, for direction. The result: moral sappiness, crispy conservatism and talk show literature, preferably nonfiction, because fiction only enhances disorder. (Dautzenberg 2013: 8)

Yet, as will become clear, the focus in Dautzenberg's media performances lies almost exclusively on the dimensions of his works that 'truly happened.' Most of his works are to an important degree autobiographical or 'based' on extra-fictional material, including 'real' celebrities from the Dutch public sphere or referring to societal issues that he seeks to put on the public agenda. I argue that this veiled emphasis on factuality under the flag of fiction to an important extent explains the efficiency of Dautzenberg's style of media performance, and helps 
the author generate attention for his work. I argue that in the final instance, both his work and his media performances are subordinate to his societal engagement, and that therefore, Dautzenberg is a public antagonist first, and an author only secondarily.

\section{The public intellectual}

According to Odile Heynders in Writers as Public Intellectuals (2015), literary authors have an important role to play as intellectuals in today's public sphere. As public intellectuals, authors are able to intervene in socio-political debates, especially when they are not afraid to voice a committed, provocative, or even a compromised standpoint. Heynders cites Jürgen Habermas who characterizes intellectuals by their "avant-gardistic instinct for relevances." This instinct entails, amongst other elements, a "sense for what is lacking and 'could be otherwise" and a "modicum of the courage required for polarizing, provoking and pamphleteering" (Habermans 2009: 55). Further, the author as a public intellectual possesses critical knowledge and ideas, inspires discussions, and provides "alternative scenarios in regard to topics of political, social and ethical nature" (Heynders 2015: 3). This way, Heynders argues, the literary author can perform as a mediator, informing a non-expert audience and stimulating them to participate in the public debate.

When we examine Dautzenberg from Heynders' perspective, we see that he certainly dares to intervene in contemporary socio-political debates, often by taking a provocative standpoint. He identifies and critiques sensitive issues such as the way society dehumanizes and outlaws pedophiles, or the public demonization and ostracism of the social psychologist Diederik Stapel after he committed large-scale scientific fraud. ${ }^{1}$ He also founded Quiet 500, a glossy on 'silent poverty' modeled after Quote 500 which lists the richest people of the country. From these examples it becomes clear that Dautzenberg is prone to defend the societal underdog.

Another feature of Heynders' public intellectual that characterizes him, is the creation of a public persona, with a blurring of the domains inside and outside the texts as a result. In the case of the 'celebrity intellectual' in particular, the lines between literature and public persona become hard to draw (Heynders 2015: 14). Hence the literary celebrity, writes Graeme Turner (2004: 13), is at least partly produced in his own writing. With Dautzenberg's oeuvre, this is certainly the case. As the author explicitly states, "I do not limit myself to writing

\footnotetext{
${ }^{1}$ See “Overzicht fraude in de wetenschap." NOS, 23 September 2013, <http://nos.nl/artikel/554459-overzicht-fraude-in-de-wetenschap.html>, retrieved 5 Oct. 2017.
} 
in-between the covers of my book, I also write outside them. For me, it's all one" (Dautzenberg 2014b). For him, moreover, this is directly related to the issue of engagement: "I refuse to let myself be enslaved by the dominant view, that expects a writer to refrain from venturing beyond the covers of a book" (Dautzenberg 2014a: 300).

Let us see how this unity plays out in his novel Samaritaan (2011b), which deals with a protagonist who donates a kidney. The novel has the form of thirty-three dialogues (a number that refers to the age at which Christ died as well as to the number of cantos in Dante's Purgatorio) between this nameless donor and others, e.g. the coordinator of the program, his father, his partner, the person making the MRI-scan, the nurse, the night nurse, and, remarkably, the kidney itself. The novel begins with listing the dictionary definitions of altruism, masochism, egotism, and anarchism. We follow the process from admission interview, via hospitalization, to the operation and its aftermath. One of the dialogues, chapter 26, confronts the drowsy protagonist, post-operation, with "the author of this book." This part performs the blurred boundaries between character, narrator and authorial persona:

Well, now I've just about seen everything.... I think the morphine dosage is too high, way too high. I'm overcome by a mystic sleep. I'll ring the nurse, so she can check the pump.

'No need. I don't mean any harm. As I said, this is an autobiographical book.'

I'm letting this sink in for a moment...

'Take your time.'

Let's say, by way of a joke, I follow my hallucination for a moment ... I'm a character in a book, your book?

'Correct.'

And that book is autobiographical?

'Also correct.'

So then in fact I'm ... you?

'Yes and no.' (Dautzenberg 2011b: 196) ${ }^{2}$

In this metafictional passage which makes reference to the book in which it is included, the character calling himself the author suggests he is in a certain sense, or partially, the protagonist. Both this author figure and the first-person narrator and protagonist share traits of the book's real, extra-fictional author. Yet at the same time, the writer in the book indicates that he does not completely coincide with the protagonist: there is a difference, but it is ambiguous, not clear-cut. The confused main character soon gets irritated, upon which the 'author' continues:

${ }^{2}$ All translations from Dautzenberg (articles, essays, novels, interviews) are mine. 
"I am the author of an autobiographical account. And because I highly esteem the genre, I want to stick to the facts. I'm a slave of reality, I closely follow reality. But... Let me finish... Buhut, that is not to say I have no influence. Of course I have influence" (Dautzenberg 2011b: 198).

Outside of the novel, the boundaries between protagonist, narrator, and author are just as indistinct. For even though the cover of Samaritaan says 'novel,' the author claims to have undergone the complex and bureaucratic process of the kidney donation in real life. He discussed his experiences on the talk show Pauw $\mathcal{E}$ Witteman (07-04-2011), where he was asked to prove the fact before coming on the program, by showing his scar. Seated in the audience was an employee of the Erasmus Medical Center, which runs the donation program. She was asked to confirm that the author had in fact received surgery and donated a kidney, to take away all doubt (Mikkers 2011). These efforts towards fact-checking suggest that Dautzenberg would not have been invited to talk about his work if it were 'pure' fiction. From the start of the interview, the author and his interlocutors focus on his alleged real-life experiences instead of the literary novel: he is asked about his motivations for the donation, claims that the positive side effects of the surgery include a higher libido, and that he met the anonymous recipient of his kidney by accident. He talks about the disease and death of his father, the reservations his girlfriend had about the operation, and also suggests that his many motivations include a death drive.

Only after 12 minutes, just before the closing of the interview, Paul Witteman points to the fact that the book they have been discussing is in fact framed as a novel: "You call it a novel which is remarkable, considering it really happened. At least we hope so, because you have somewhat of a curious reputation, since sometimes you publish interviews with people you've never spoken to [...] To what extent can you guarantee the reader that this has really happened to you?" Dautzenberg replies that "It simply is a good book. It doesn't matter if it's true, I mean, I did donate a kidney, but I don't think the facts matter much." Here, we see that in his public performance, the author deliberately creates a sense of mystery and ambiguity about his life. His trademark blending of fact and fiction in both his media presence and his literary works also serves to distort the boundaries between authorial persona and work, in the manner of the public intellectual. His interviews are completely in line with a development signaled by Sander Bax in his forthcoming work De Literatuur Draait Door, of authors receiving more attention in the media when they focus on current topics (Bax, manuscript).

A performance on the TV program KRO Goudmijn (10-03-2011) proceeds along similar lines. Interviewer Karin de Groot exclusively asks questions about the decision of organ donation, and does not allude once to the fact that Dautzenberg 
has written a literary work. Later, in a collection of stories, he includes a 'self-interview,' "A.H.J. Dautzenberg2," claiming that he in fact never donated a kidney: "It was posturing, promotional chit-chat. I expected that people would see through it. Apparently not. [...] A writer can, no must, confabulate" (Dautzenberg 2014a: 62). In De Fictiefabriek (2014), he retracts that prior statement by emphasizing it was made within a literary text. This does not clarify matters, considering the facts that De Fictiefabriek is itself a literary text and his proclamation, cited above, that his literature extends beyond the covers of his books. Several media, including radio news programs and newspapers, took his denial of the operation for a news fact and presented it as such: "Writer Dautzenberg from Tilburg fabricated donation" (Brabants Dagblad, 18-01-2017).On the radio show Nooit Meer Slapen (17-01-2014) the author commented that he refuses to offer clarification.

According to Graeme Turner (2004), it is a defining characteristic of the celebrity that they receive more attention for their private lives than for their public achievements. This is decisively not the case with Dautzenberg, who is seldom asked by his interviewers about his private life. As Bax (2015:30) argues, in order to be successful in the media, the writer should strategically reveal information about himself in small doses, thus creating a media myth around himself. If Dautzenberg had a media myth, it would consist of the aforementioned 'guessing game' surrounding the question of what is real and what is fictive in his work and life, for instance: did he really donate a kidney?

Samaritaan is one node in a larger play with fact and fiction that includes novel, author, media performances, and audience. It is impossible to draw a line around this book and disregard the author's persona outside of it. Moreover, he claims that at last four of his readers were inspired by Samaritaan to donate a kidney (Fortuin 2015). His ongoing play with the boundaries of fact and fiction cause authorial persona and oeuvre to conjoin. In this respect, Dautzenberg clearly fits Heynders' theory of the public intellectual.

\section{The public antagonist: commitment as suffering}

When we look at Dautzenberg's own take on what a writer as public intellectual should be, however, he appears to be at least partially at variance with Heynders' theoretical model. In an article written for NRC Handelsblad (Dautzenberg 2014c), Dautzenberg signals an absence of literary authors in European intellectual debates today. This was different in the nineteen sixties and -seventies, he writes, when Willem Frederik Hermans and Gerard Reve put their self-interest aside in order to defend the freedom of opinion: "The meaning of their work for the freedom of speech, for the fight against repressive morality, is not to be 
underestimated. They realized that a healthy democracy demands a healthy capacity for resilience. An antagonistic attitude, a fair amount of anomie is essential to maintain this" (Dautzenberg 2014c).

Antagonism and anomie are exactly what Dautzenberg claims today's authors are missing. His fellow writers, he complains, all succumb to commercial logic and the entertainment industry: afraid to lose readers, they seek foremost to entertain, in order to gain in popularity and capital. To offer one example, he derides his contemporary Ronald Giphart, who once was a 'controversial' writer, for writing a cookbook. Authors like him, who do not dare to make themselves heard, form a threat to society according to Dautzenberg: "A dentist who does not dare to hurt creates bad teeth, and will eventually be without customers. It's about time that writers once again dare to fire their poisoned arrows while loudly chanting: death to the people! It would bring literature back to life" (Dautzenberg 2014c).

Heynders sees the public intellectual as a mediator between the non-expert audience and topics of public interest: a mediator who provokes and titillates, but also unites and builds bridges. She underlines that today more than in earlier times, the public intellectual functions in a mediatized context which intensifies or diminishes his or her position (Heynders 2015: 5). Crucial to her model is that public intellectuals need to popularize their ideas to a certain extent in order to render them accessible to, and attractive for the public (Heynders 2015: 9). This is where her and Dautzenberg's views diverge. The latter exclusively emphasizes the public intellectual's counter-cultural traits. He seeks to raise confusion and disorder rather than consensus (Thomèse 2015). Writers, he feels, should be able to "irritate, confuse, and wound, no matter the consequences" (Dautzenberg 2014c). Moreover, he understands this figure foremost as a problem. It is no coincidence, he claims, that none of his contemporaries dare to enter the public arena. For acting as a committed writer in this sense comes with a price: Engagement is "commercial suicide" (Dautzenberg 2014c).

The author himself has experienced the negative consequences of his societal engagement and antagonistic stance on myriad occasions. In 2011, he publicly declared solidarity with Vereniging Martijn, the association for pedophiles which was prohibited in 2014, by becoming a member (Dautzenberg 2011a). The consequences of this act of commitment were far-reaching. He received death threats, his family and partner were harassed, the company he co-owned (a communication bureau for economic and journalistic projects) went bankrupt. Colleagues turned their back on him, he got invited for lectures less often, and several booksellers boycotted his works: "The last three months I received no income. I'm living off my savings. Luckily, I'm not the materialistic type" (Berkeljon 2012).When he started working together with Diederik Stapel, ex-professor of cognitive social psychology who was convicted for large-scale fraud in his 
scientific publications, Dautzenberg was fired from his appointment as a columnist for a university newspaper.

In the media, the author repeatedly emphasizes all his suffering caused by the choice to commit himself. He positions himself as somewhat of a martyr: "I have some sort of Berufsverbot. [...] I am radioactive waste" (Fortuin 2015). In this respect, he revisits a Romantic sensibility of authorship: the notion of the suffering artist. As Marita Mathijsen (2013) has noted, the nineteenth century was marked by the admiration and elevation of solitary artists, whom society had neglected during their lives. Suffering, poverty, and tragedy were considered proof of these artists' worthiness of this posthumous apotheosis. The literature of the doomed, Promethean, struggling writer is created at great costs for himself.

This is exactly the self-image that Dautzenberg creates by underlining the hardship brought about by his commitment. His performance of a Romantic martyrdom becomes a thematic focus and trope in De Fictiefabriek (2014). This text is framed as a "liberation novel in letters and an inspired ode to the power of imagination" (back cover). It contains an e-mail correspondence between Dautzenberg and Diederik Stapel - or rather their fictional alter egos, for we are again writing about a novel. The men write about their plans for a theatre show (and their troubles trying to find a theatre programmer who will host it), as well as their ideas on literature, film, science, and events from their own lives. But first and foremost, they write about their experience of being outcast by society. Stapel, after the discovery of his fraud in 2011, was charged and lost all his official functions. He describes how he is condemned to perform community service in a graveyard, where he is expected to evacuate graves. After his punishment has been executed, he feels in no way absolved from his crimes: "I could explain myself in a thousand ways," his alter ego in the novel complains, "but it will never be enough. It will always be complicated and uncomfortable" (Dautzenberg and Stapel 2014: 194). The Dautzenberg in the novel can relate: artists refuse to perform with him, festivals eliminate him from their programs, and colleagues turn their backsto him: "we are both reviled, you a bit more than I, but we both have a stigma" (Dautzenberg and Stapel 2014: 27). For pages on end, they revel in their respective underdog positions.

We see that here in De Fictiefabriek as in Dautzenberg's media performances surrounding it, a Romantic model of authorship is revisited and played out, which pictures the author as a rebel and outsider. Far from Heynders' model of the public intellectual as a figure who operates from the fringes of society, yet brings people together by offering a "popularizing [...] perspective on issues of general concern" (Heynders 2015: 21), Dautzenberg seems to seek to antagonize his audience and inspire unrest and disorder, to solicit engagement through negative stimuli. 


\section{The autonomous writer: between $20^{\text {th }}$ - and $21^{\text {st }}$ century models}

The case that undoubtedly brings out this anti-popular stand in Dautzenberg the most clearly, is his support for, and membership of, Vereniging Martijn. Although he does not have pedophiliac tendencies himself and opposes child abuse, he expresses the need to revolt against the witch hunt on pedophiles: "[p]edophilia is as old as humanity. It belongs to humans, it is a constant factor, and still we refuse to accept it. And besides, how vehemently we are against it varies from one decade to another. I find that fascinating" (Fortuin 2015). He further makes an appeal to his profession as a literary author in order to underwrite the problem he has with this development, explaining that to him, it is an affront when people can be condemned for their dreams, fantasies, and desires instead of their deeds: "Before we know it the writer will be forbidden to confabulate [...] about societally sensitive subjects. In that regard, [the issue] certainly has a literary aspect" (Ibid.).

And again, Dautzenberg has written a literary novel as an imaginative reflection on a societal theme he seeks to put on the public agenda: in this case, the witch hunt for pedophiles. In Wie zoet is (2015), Arnold Veltkamp, a neurotic, middle-aged payroll administrator travels cross-country to interview men who yearly dress up as Sinterklaas for the eponymous national children's holiday, and publishes these interviews on his weblog. It also includes the responses to this blog. Soon it becomes clear that the interviewer, who recently quit his psychotropic medication, is suffering from a childhood trauma related to this kindervriend. All the conversations turn to insinuations concerning the sexual pleasures of playing Sinterklaas: the protagonist is on the hunt for pedophiles. The second part of the novel consists of letters written by Nol, a Sinterklaas taken hostage by the interviewer, addressed to his partner Theo. Prints of the interviews from the first part are shoved under the door of the room Nol is locked in, for him to read. In the fourth part, a switch is made to an objective narratives perspective which offers an alternative picture of what really happened with Arnold Veltkamp. Truth, the plot twist at the end seems to suggest, is a matter of perspective and the stories we choose to believe in. Other themes include the search for a scapegoat (the book is larded with many references to the Old Testament and the Bible book of Revelation, prejudice, (internet) populism, and the use of deceit and hypocrisy to sustain a fixed morality. In this particular instance, the novel which deals with the societal issue of the witch hunt on pedophiles almost seems like an afterthought. When we look at Dautzenberg's performances in the media (e.g. in Pauw E Witteman, 1 Vandaag), they all deal exclusively with the Vereniging Martijn, none is devoted to his novel, which came years after and did not generate commotion. His 
membership is a provocative and forceful gesture, a statement that completely overshadows and drowns out the novel.

Again, we see a divergence with the model of the public intellectual that both Heynders and Habermas adhere to. According to them, this figure offers various perspectives on the same issue and, notably, does so from a position of detachment (Heynders 2015: 119). We could say he lacks a certain measure of autonomy that characterizes the public intellectual. To clarify this, we should look more closely at what literary autonomy consists of. In De Mulisch Mythe, Sander Bax (2015: 96) distinguishes four forms of autonomy that characterize the model for authorship that dominated the twentieth century: independence (e.g. from economic interests), disinterestedness (in politics), unicity (by way of severing his ties with the commercial and political realms), and fictionality (the unrestricted creation of another world in which anything can be said).

When we place Dautzenberg on this scale, it is clear that he succeeds in attaining a form of independence. As said, he sacrifices part of his income for the defense of the right of free speech. Unicity can be ascribed to him in the sense that he often proclaims a minority viewpoint and that he undertakes actions that almost none other would consider: becoming a member of a union for pedophiles to make a statement, donating a kidney to a stranger, or supporting a convicted fraudster. Fictionality is one of his proclaimed core values, especially the right of the literary author to freely 'confabulate' and the literary work as a free place for unrestricted imagination. But when we look at Bax's second form of autonomy, disinterestedness, we see that Dautzenberg diverges from this category precisely by committing himself. Here, it seems that autonomy is hostile to his specific form of engagement, for which 'commitment' would indeed be a more fitting term. By completely devoting himself to the 'boys of Martijn' or Diederik Stapel, he leaves no room for the detachment of the intellectual. This is an important difference.

In De literatuurdraait door, Bax (manuscript) further proposes a twenty-first-century model for literary authorship in which he signals that autonomy has been compromised as authors increasingly practice self-branding and become media figures. The premises of literary autonomy, he claims, are at odds with the expectations of our current media culture from literary authors and their work. Writers who use the mass media to seek out attention from large audiences have to look for ways to bridge the gap between a twentieth-century focus on literary which has not altogether lost its force today, and the twenty-first-century perspective of our media culture. This considerably changes the four types of autonomy he signaled earlier. Instead of being independent from economic interests, the author sells his or her work in the media. Rather than being disinterested in what is being discussed in society, the author focuses on current events and 
uses a populist discourse. Rather than being unique, the author performs in the media amidst other celebrities. And instead of being pure fiction, the language of the media, autobiography and current events infiltrate the novel.

When we place Dautzenberg in this frame of the twenty-first-century authorship in which the demands of media presence eclipse the demand for literary autonomy, we see that even though the latter has a strong media presence, he does not exactly sell his works through his performances in the media. As noted, often his literature is barely discussed in the television and radio shows on which he appears: the societal issues he brings to the table tend to divert from his works. What is more, he claims that his engagement with controversial topics in fact causes a decrease in commercial success. Unsurprisingly, becoming a member of an association for pedophiles does not help to sell books. "If I'd wanted to generate publicity to sell more books, I would have to choose a different strategy. At my publishing house they say I shouldn't be talking about Martijn, but I do it anyway" (Fortuin 2015).When we look at the other shifts that Bax mentions, we note that Dautzenberg does focus on current events but, as said, refrains from populist (or even popular) arguments. His media performances are always against the grain, hence he does not manifest himself as 'yet another celebrity,' - something that he accuses his colleague Giphart of.

The last shift Bax points out, from an emphasis on fiction to one on current events, is particularly notable in Dautzenberg's case. For an author who claims that fictionalizing is the highest priority and one of the most important rights of the literary author, it is typical that all his works are to an important extent autobiographical or (allegedly) based on non-fictional material. The nameless protagonist in Samaritaan is a writer, freelance journalist, and economist, who in the novel introduces himself in a manner very similar to Dautzenberg's manner of speech: "I'm an economist and I prostitute myself [...] I work as a freelance journalist slash text writer" (Dautzenberg 2011b: 17). This is almost literally repeated by the author on Pauw $\mathcal{E}$ Witteman. Furthermore, several passages note that the protagonist plans on writing a book about his organ donation. The main characters in the 'epistolary novel' De Fictiefabriek are called Dautzenberg and Stapel, and are in no way distinguishable from the authors of the book, which gives rise to the question why they chose to frame this work as a novel.

Wie zoet is has a main character that diverges considerably more from the author, and this is obviously the least autobiographical of his works. Yet, the novel is reportedly based on 'real-life' material. It figures 'real-life' Dutch celebrities such as Henk Bres, the tattoo artist who is notorious for his aggressive stance toward pedophiles. In the "Justification" section of Wie zoet is, Dautzenberg writes that the story is based on true facts: he allegedly used the letters, diary, and notes of a psychically traumatized person. Yet, considering the fact that this paratext 
is printed within the novel and not at the end as is, quite rightly, customary and considering the author's predilection for blurring the boundaries between fact and fiction, this is not to be accepted without problems. Still, the reader is obviously not meant to forget that the issues addressed in Wie zoet is are in fact pressing problems in the Dutch public sphere today. In the play with fact and fiction that Dautzenberg is famous for, the balance tips in favor of the factual each time. This gives rise to the impression that in the final instance, his works are at the service of his societal engagement instead of the other way around.

\section{Conclusion}

I set out in this article from the question whether it was possible, considering the diverging types of output that Dautzenberg had brought forth, to construe a unified image of his authorship, literature, and public persona. I asked whether his socio-ethical commitment can be reconciled with his will to provoke, his anti-establishment stance, and his play with truth and fiction, and integrated in a model for an engaged, contrarian authorship for our current time, or whether these roles collide and detract from the effect of both work and engagement. I set the case of Dautzenberg's work, public engagement, media performances, and persona, against concepts of the public intellectual, the twentieth-century (modernist) autonomous writer, and the twenty-first-century star author. We have seen that in each case, the case study only fits the model or theory to a certain extent. Each time a field of tension emerged, as I argued Dautzenberg refuses to be pigeonholed and therefore brings out the limits of any typology of authorship. This has shown that models and theories of literary authorship and public engagement are an approximation, and necessarily simplified.

The image that emerged from my analysis was that of the author as what I chose to call a 'public antagonist,' a rebel and an outsider, rather than a public intellectual. Departing from Heynders' model of the public intellectual as a figure who offers a popularizing perspective on issues of public concern, Dautzenberg provokes and antagonizes his audience and deliberately causes chaos, soliciting engagement via negative stimuli. In his media performances, I furthermore argued, he plays out a Romantic model of authorship.

I signaled a discrepancy in Dautzenberg's texts and extra-textual commitment: while he underlines the importance of fictionalization and the right of the author to imagine time and again, and expresses disdain for the omnipresent and popular 'true story,' we have seen that the focus in his media performances is almost exclusively on the non-fictional and autobiographical elements in his works and the issues that he seeks to place on the public agenda. I argued that 
this oblique focus on factuality under the flag of fiction goes some way to account for the effect of Dautzenberg's style of media performance, as it generates attention for his work. In the last instance, I claimed, both oeuvre and media presence are subservient to his societal engagement. Dautzenberg, I concluded, is a public antagonist first, and an author only secondarily. He does so, by constantly emphasizing the sacrifices he makes for his engagement in interviews and in De Fictiefabriek, and the suffering this causes.

In our evaluation of Dautzenberg as an autonomous writer according to Bax's model of twentieth-century authorship, we noticed that he deviated from this model in the aspect of disinterestedness, as his particular branch of commitment lacked any detachment from the causes he defends. Precisely for that reason, he does not fall within Heynders' and Habermas' notion of the public intellectual, which implied a certain distance and independence from the issues addressed. The most obvious example of this discrepancy in concepts of commitment is his membership of Martijn. By completely devoting himself to his causes, Dautzenberg leaves no room for the detachment of the public intellectual.

Measured by Bax's twenty-first-century model of literary authorship where autonomy has progressively been eclipsed by self-branding and media presence, we noted that Dautzenberg, despite his strong media presence, far from sells his literature in the media. On the contrary: his media performances often lead to a decrease in commercial success because of the controversial topics he chooses to bring up and the underdogs he defends. His media performances are decisively against the grain.

\section{Bibliography}

Bax, Sander. 2015. De Mulisch Mythe. Harry Mulisch: schrijver, intellectueel, icoon. Amsterdam: Meulenhoff.

. Manuscript. De Literatuur Draait Door. Over de literaire schrijver in het mediatijdperk.

Bell, Stephen and Anne Punt. 10 Oct. 2014. "Anton Dautzenberg heeft schijt aan de waarheid en wij ook." Vice. 17 Oct. 2017. <https://www.vice.com/nl/article/mv8n5v/ anton-dautzenberg-heeft-schijt-aan-de-waarheid-en-wij-ook-237>.

Berkeljon, Sara. 8 Sept. 2012. "Mijn ego zat gevangen in verlegenheid. Interview with A.H.J. Dautzenberg." de Volkskrant. 1 Apr. 2017. <https://www.volkskrant.nl/ archief/-mijn-ego-zat-gevangen-in-verlegenheid a3312962/>.

Cloostermans, Mark. 29 Oct. 2015. "De Zak van Sinterklaas. Review of Wie zoet is." De Standaard der Letteren. 15 Oct. 2017. <http:/ / markcloostermans.blogspot.nl/2015/10/ recensie-in-de-zak-van-sinterklaas.html>.

Dautzenberg, A.H.J. 20 July 2011(a). “A.H.J. Dautzenberg wordt lid van Martijn.” 15 Oct. 2017. <http://www.ahjdautzenberg.nl/2011/07/a-h-j-dautzenberg-wordt-lid-van-martijn/>. 
2011b. Samaritaan. Amsterdam/Antwerpen: Atlas Contact.

2013. Rafelranden van de Moraal. Novelle. Amsterdam/Antwerpen: Atlas Contact.

2014a. En dan komen de foto's. Amsterdam/Antwerpen: Atlas Contact.

21 March 2014(b). "Ik schrijf ook buiten de kaft van een boek." The Post Online

Magazine. 15 Oct. 2017. <http:/ / www.elinea.nl/artikel/anton-dautzenberg-ik-schrijf-ook-buiten-de-kaft-van-een-boek>.

25 July 2014(c). "Een te kleine broek maakt je impotent." NRC. 17 Oct. 2017. <https://www.nrc.nl/nieuws/2014/07/25/een-te-kleine-broek-maakt-je-impotent1402864-a783668>

. 21 Nov. 2015(a). "Schrijvers, waar is uw engagement?" NRC. 17 Oct. 2017. <https:// www.nrc.nl/nieuws/2015/11/21/schrijvers-waar-is-uw-engagement-1557826-a625950>

2015b. Wie zoet is. Amsterdam/Antwerpen: Atlas Contact.

Dautzenberg, Anton and Diederik Stapel. 2014. De Fictiefabriek. Een bevrijdingsroman in brieven. Amsterdam/Antwerpen: Atlas Contact.

Fortuin, Arjen. 3 Jan. 2015. "Ik sticht verwarring, ja." Interview with A.H.J. Dautzenberg. NRC. 21 Oct. 2017. <https://www.nrc.nl/nieuws/2015/01/03/ik-sticht-verwarring-ja-1452860-a389010>.

Habermas, Jürgen. 2009. Europe, The Faltering Project. Trans. Ciaran Cronin. Cambridge: Polity.

Heynders, Odile. 2015. Writers as Public Intellectuals: Literature, Celebrity, Democracy. Basingstoke: Palgrave Macmillan.

Moran, Joe. 2000. Star Authors. Literary Celebrity in America. London: Pluto.

Mathijsen, Marita. 2013. Historiezucht: De obsessie met het verleden in de negentiende eeuw. Nijmegen: Vantilt.

Mikkers, Jasper. 10 Apr. 2011. "Samaritaan van A. Dautzenberg. Integere roman, feest van sarcasme." Brabant Cultureel. 21 Oct. 2017 <http://jaspermikkers.nl/2011/04/ samaritaan-van-a-dautzenberg-integere-roman-feest-van-sarcasme/>.

Missinne, Lut. 2013. Oprechtgelogen. Autobiografische romans en autofictie in de Nederlandse literatuur na 1985. Nijmegen: Van Tilt.

“Overzicht fraude in de wetenschap." 23 Sept. 2013. NOS. 1 Nov. 2017. <http://nos.nl/ artikel/554459-overzicht-fraude-in-de-wetenschap.html>.

Redmond, Sean. 2014. Celebrity EThe Media. New York: Palgrave MacMillan.

Serdijn, Danielle. 16 Apr. 2011. “Onbaatzuchtigheid bestaat niet.” de Volkskrant. 1 Nov. 2017. <https://www.volkskrant.nl/archief/onbaatzuchtigheid-bestaat-niet a1876223/>.

Storm, Arie. 27 Apr. 2011. "Pretfiguur schenkt nier." Het Parool: 17.

“Tilburgse auteur Dautzenberg verzon donatie." 17 Jan. 2014. Brabants Dagblad.

Thomèse, P.F. 2015. "Speechat booklaunch Wie zoet is." 21 Oct. 2017. <http://www. tzum.info/2015/09/nieuws-elk-boek-van-dautzenberg-is-een-baksteen-door-de-glanzende-etalageruit-van-de-nederlandse-winkel-vol-tevredenheid/>.

Turner, Graeme. 2004. Understanding Celebrity. Ann Arbor: Sage.

Wallace, David Foster. 1993. "E Unibus Pluram: Television and U.S. Fiction." Review of Contemporary Fiction 13(2): 151-194. 